\title{
Carta a los médicos jefe de los asilos de $\operatorname{locos}^{1}$
}

Señores,

las leyes y la costumbre les conceden el derecho de medir el espíritu. Esta jurisdicción soberana, temible, la ejercen con su entendimiento. Déjennos reír. La credulidad de los pueblos civilizados, de los científicos, de los gobernantes, adorna a la psiquiatría de vete a saber qué luces sobrenaturales. El juicio a su profesión está sentenciado de antemano. No pretendemos discutir aquí el valor de su ciencia ni la dudosa existencia de las enfermedades mentales. ¿Pero compaginan ustedes alguna tentativa noble para ponerse en contacto con el mundo cerebral donde viven tantos de sus prisioneros por cada cien patogenias pretenciosas donde se desata la confusión entre materia y espíritu, por cada cien clasificaciones de las que las más vagas siguen siendo las más útiles? ¿Para cuántos de ustedes el sueño de un demente precoz, las imágenes que le apresan, son algo más que una ensalada de palabras?

No nos asombra encontrarles inferiores para una tarea para la que hay pocos predestinados. Pero nos sublevamos contra el derecho atribuido a los hombres, limitados o no, de sancionar con el encarcelamiento perpetuo sus investigaciones en el campo del espíritu.

¡Y qué encarcelamiento! Se sabe -no lo bastante- que los asilos lejos de ser asilos, son prisiones espantosas donde los detenidos suministran mano de obra gratuita y cómoda, donde la crueldad es regla, y todos toleran esto. El asilo de alienados, bajo el manto de la ciencia y la justicia, es comparable al cuartel, a la prisión, al presidio.

No plantearemos aquí la cuestión de los internamientos arbitrarios, para evitarles la molestia de una salida fácil. Afirmamos que gran número de sus huéspedes, perfectamente locos según la definición oficial, están internados arbitrariamente. No admitimos que se obstaculice el libre desarrollo de un delirio, tan legítimo, tan lógico como cualquier otra sucesión de ideas o de actos humanos. La represión de las reacciones antisociales es tan quimérica como inaceptable. Todos los actos individuales son antisociales. Los locos son las víctimas individuales por excelencia de la dictadura social; en nombre de esta individualidad que es lo propio del hombre, exigimos que se libere a estos galeotes de la sensibilidad, pues además no es potestad de las leyes encerrar a todos los hombres que piensan y actúan.

\footnotetext{
«Lettre aux médecins-chefs des asiles de fous», La révolution surréaliste, 3, 15-4-1925, p. 29; trad. Ángel Cagigas.
} 
Sin insistir en el carácter perfectamente genial de las manifestaciones de algunos locos, en la medida en que somos capaces de apreciarlas, afirmamos la legitimidad absoluta de su concepción de la realidad y de todos los actos que de ella se desprenden.

Recuérdenlo mañana por la mañana a la hora de la visita, cuando intenten sin léxico hablar con estos hombres sobre los que, reconózcanlo, no tienen más ventaja que la de la fuerza. 